\title{
Predictors of Clinical Decision Rule in Hydrocarbon Intoxicated Cases Admitted to Poison Control Center Ain Shams University Hospitals during 2015-2016
}

\author{
Hany M. Tawfik ${ }^{1}$ and Rabab Nabil Hafiz. ${ }^{2}$ \\ ${ }^{1}$ Poison Control Center, Ain Shams University Hospitals, Egypt \\ ${ }^{2}$ Department of Forensic Medicine and Clinical Toxicology, Faculty of Medicine, Ain Shams University, Egypt.
}

\begin{abstract}
Hydrocarbon toxicity is a common cause of death among cases admitted to poison control centers due to its dangerous complications. The Aim of this study is to derive a clinical decision rule and to identify predictors of outcome after hydrocarbon poisoning. Methods: The prospective study included 674 cases admitted to the PCC ASU hospitals during the years 2015 - 2016. All cases subjected to full history ,clinical data and detection of acid base status by measuring ABG. Emergency interferences were evaluated. Results:563 cases were due to kerosene poisoning, 111 cases were due to benzene poisoning .There was significant difference between the two types of hydrocarbon poisoning regarding admission, while there was no significant difference regarding death, mechanical ventilation and CNS abnormalities. 98.5\% of cases lived,1.5\% died. 33.5\%of cases were in the age group $>1-\leq 2$ years, $17.7 \%>18-\leq 40$ years, all dead cases were children and $40 \%$ of deaths were in the age group ( $>2-\leq 3$ years).Most of cases were males $(65 \%)$ without significant difference between both genders. $71.2 \%$ were accidental, $28.5 \%$ were suicidal and $0.3 \%$ were criminal mode of toxicity. $77.6 \%$ used oral route, $15 \%$ were dermal and $7.4 \%$ were by injection. $88.6 \%$ of cases needed observasion in the ER for $<6 \mathrm{~h}, 4.7 \%$ admitted to the inpatient word, $6.7 \%$ admitted to ICU.5.6\% of cases admitted for 1 day, 3\% for 2 days, $1.5 \%$ for 3 days, $0.7 \%$ admitted for 1 week and $0.6 \%$ for $>1$ week. 12 cases needed endotracheal intubation and mechanical ventilation, 5 cases were shocked and needed dopamine as vasopressor, 31 cases received corticosteroid, 45 cases received bronchodilator by nebulizer and all cases received $\mathrm{O} 2$ therapy and antibiotics. Of symptomatic survived cases, 66\% , $70 \%, 67 \%, 46 \%, 9 \%$ and $1.5 \%$ had hyperthermia, tachycardia ,respiratory distress, acidosis, CNS abnormalities and hypotension respectively. All dead cases had hyperthermia, tachycardia, respiratory distress, acidosis and 50\% had hypotension and 60\% had CNS abnormalities.Lastly, Mchanical ventilation was used in $3 \%$ of symptomatic survived group and $100 \%$ of the dead group. The group of deaths showed significant predominance of hyperthermia, tachycardia, hypotension, respiratory distress, CNS abnormalities, acidosis and need of mechanical ventilation when compared with the survivors group. The Logistic regression analysis revealed that hypotension, CNS abnormalities, acidosis and need of mechanical ventilation all are predictors of in-hospital mortality Conclusion: Hydrocarbon poisoning is common oral accidental toxicity among children in the age group $>1-\leq 2$ years .Predictors of fatal outcome are: children especially the age group $>2-\leq 3$ years, hypotension, CNS abnormalities, acidosis, respiratory distress, hyperthermia and tachycardia. Recommendations: Any case presented with the previously mentioned predictors should be considered as a high risk group for proper management and in order to decrease risk of fatalities. Preventive measures should be done as awareness of parents about hydrocarbon toxicity, proper packing and storage of such dangerous materials.
\end{abstract}

Keywords hydrocarbon, hyperthermia, tachycardia, hypotension, respiratory distress, CNS abnormalities, acidosis.

\footnotetext{
Introduction

$\mathrm{H}$ ydrocarbons are organic substances that contain carbon and hydrogen. They are generally liquid at room temperature. All petroleum distillates (eg, kerosene, gasoline, mineral seal oils, and naphtha) are hydrocarbons; however, not all hydrocarbons are petroleum distillates. Turpentine, for example, is a
}

hydrocarbon made from pine oil. (Lewander and Aleguas, 2011).

The four structural classes of hydrocarbons are: aromatic, halogenated, aliphatic, and terpene. Aromatic hydrocarbons are cyclic compounds containing a benzene ring (eg, benzene, toluene, and xylene). They 
are used primarily in solvents, glues, nail polishes, paints, and paint removers (Borne et al., 2005). Halogenated hydrocarbons are fluorinated, chlorinated, or brominated (eg, methylene chloride, chloroform, carbon tetrachloride, trichloroethylene, tetrachloroethylene). The aliphatic hydrocarbons are petroleum distillates such as gasoline, kerosene, and naphtha. They are found in furniture polishes, lamp oil, and lighter fluid. The terpenes include turpentine and pine oil. (Lewander and Aleguas 2007). Unlike the aromatic or aliphatic hydrocarbons, the halogenated hydrocarbons tend to cause a wider range of toxicity (Levine, 2015).

Hydrocarbons also can be classified according to their toxicity: (Lewander and Aleguas 2007)

- Nontoxic (unless complicated by gross aspiration): Examples include asphalt, tars, mineral oil, liquid petrolatum, motor oil, axle grease, baby oil.

- Aspiration hazard: Clinical effects typically are limited to direct pulmonary damage and subsequent inflammation. Examples include turpentine, gasoline, kerosene, mineral seal oil (furniture polish), charcoal lighter fluid, cigarette lighter fluid, and mineral spirits.

- Systemic toxicity:Occurs mostly with halogenated and aromatic hydrocarbons.

Hydrocarbons used in the domestic environment are still frequently stored in the home or garage in unmarked containers or beverage bottles. They may also have attractive aromas and be brightly coloured. It is not surprising therefore that most cases of exposure in the home involve accidental ingestion by young children. (Seymour, 2001).

Hydrocarbon aspiration is a medical emergency and a potential cause of severe pneumopathy with clinical characteristics, radiological patterns and outcome depending on the type of hydrocarbon inhaled (Levine, 2015). However Seymour (2001), reported that abnormal initial radiographs in asymptomatic patients were not necessarily associated with a complicated course, still he agreed with the study of Abd El Salam et al., (2011) who found that radiographs were inferior to clinical signs and its correlation was insignificant to complete recovery and hospital mortality in patients with acute hydrocarbons toxicity.

The toxicity of hydrocarbons is due to their low surface tension and vapor pressure which helps them spread over large surface area of the lungs and cause chemical pneumonitis (Schneider et al., 2013).

While lower surface tension helps in spreading over a large area, lower viscosity enhances penetration into distal airways leading to severe necrotizing pneumonia. Thus compounds like kerosene, gasoline and naphtha with high volatility, low viscosity, and low surface tension are more likely to be aspirated and cause severe lung injury (Sankar 2010).

Systemic effects include cardiac arrhythmia and central nervous system (CNS) depression (Lewander and Aleguas 2007).

In addition to halogenated and aromatic hydrocarbons, hydrocarbons that are combined with toxic additives (eg, organophosphates ,heavy metals, camphor) also have systemic toxicity (Primm, 2008).

Physicians have difficulty in estimated risks of diseases; frequently erring towards overestimation, perhaps due to cognitive biases such as base rate fallacy in which the risk of an adverse outcome is exaggerated (Osheroff,2012 )A clinical decision rule (CDR) is a type of medical research study in which researchers try to identify the best combination of medical sign, symptoms, and other findings in predicting the probability of a specific disease or outcome(McGinn et al.,2000). CDR when effectively applied contributes to increased quality of care and enhanced health outcomes, error and adverse event avoidance, improved efficiency, reduced costs, and enhanced provider and patient satisfaction (FDA, 2014).

\section{Aim of the work:}

The aim of this study is to derive a clinical decision rule and to identify predictors of outcome after hydrocarbon poisoning by demonstrating the relationship between demographic, clinical findings, acid base status, emergency management and mortality among cases presented with acute hydrocarbon poisoning in the Poison Control Centre, Ain Shams University Hospitals (PCC-AUH).

\section{Subjects and Methods:}

This research conducted as a prospective study included 674 cases presented to PCC, Ain Shams University Hospitals with acute hydrocarbon poisoning during the years 2015 - 2016. All cases subjected to full history taking included general characteristics (age, sex, residency, mode and route of intoxication), clinical data including vital signs (pulse, blood pressure, temperature, respiratory rate) and full systemic examination, in addition to detecting acid base status by measuring arterial blood gases. Emergency interferences were evaluated including endotracheal intubation, mechanical ventilation and use of dopamine.

\section{Exclusion criteria:}

Cases with history of respiratory, central nervous system or cardiac disease.

Co-exposure to other drugs which affect level of consciousness or cardiovascular function.

Toxicity with hydrocarbon that are combined with any toxic additive.

\section{The cases were classified into 3 groups}

Asymptomatic group: included 597 cases presented with hydrocarbon poisoning with no symptoms or signs and

observed for $<6 \mathrm{~h}$ and discharged.

Symptomatic survived group: included 67 cases presented with hydrocarbon poisoning with different symptoms

and signs and discharged after receiving treatment either in inpatient word or in ICU.

Symptomatic died group: included 10 symptomatic cases who died in spite of receiving appreciate treatment.

\section{Statistical analysis:}

The data was analyzed using SPSS statistical software (11.5.0; SPSS Inc., Chicago, IL). Differences between survivors and fatalities were tested using the 
chi-square test. A p value $<0.05$ is considered statistically significant. Logistic regression analyses were applied to adjust for confounders and to identify significant predictors of outcomes (Dahiru, 2008).

\section{Ethical consideration:}

Permission was obtained from the Director of the PCC and the ethics committee, Ain Shams University Hospitals. All data were stored anonymously. Written informed consent taken from cases or their legal relatives.

\section{Results:}

Among 21898 and 23680 cases visited the PCC, Ain Shams University Hospitals during the year 2015 and 2016 respectively, 339 cases (1.5\%) and 335 cases (1.4\%) were diagnosed as hydrocarbon poisoning respectively (Table1).Most of cases (563) were due to kerosene poisoning, 55 cases needed admission, 8 died, 9 mechanically ventilated and 8 presented with CNS abnormalities.111 cases were due to benzene poisoning ,22 cases needed admission,2 died,3 mechanically ventilated and 4 presented with CNS abnormalities . There was significant difference between the two types of hydrocarbon poisoning regarding admission, while there was no significant difference regarding death, mechanical ventilation and CNS abnormalities (Table2).

$88.6 \%$ of the cases were observed for $<6 \mathrm{~h}$ in the Emergency Room (ER), while $4.7 \%$ of the cases needed admission in the inpatient ward and 6.7\% admitted to ICU (Table3). Mortality rate was $1.5 \%$ (10 out of 674 patients) (Table4). Most of cases were from Cairo $69 \%$ and $17 \%$ were from Kalioubeya (Table5).

As regards the age group, most of cases were in the age group $>1-\leq 2$ years $(33.5 \%)$ followed by age $>18$ - $\leq 40$ years $(17.7 \%)$, all died cases were children less than or equal to 5 years and most of these deaths (40\%) were in the age group ( $>2-\leq 3$ years). There was significant difference in all group of age when comparing the 3 groups together except the age group $>5-\leq 12,>12-\leq 18$ and $>40-\leq 70$ years (Table 6). Most of the cases were males $(63.6 \%)$ and there is no significant difference between all groups as regard sex (Table7).

It was also noted that $71.2 \%$ of cases were due to accidental poisoning, $28.5 \%$ were suicidal, most of deaths (8 cases) were due to accidental poisoning and the criminal cause was only present in the died group. There is significant increase in the accidental poisoning in symptomatic survived and died groups and most of suicide patients were asymptomatic with significant difference when compared with survived and died groups (Table 8). 97\% of cases were due to oral route while $2.3 \%$ were due to dermal route of poisoning and the injection route was $0.7 \%$ and only present in symptomatic survived group. There was no significant difference in the oral and dermal route between the all groups and significant increase in the injection route in the symptomatic survived group (Table 9).

597 (88.6\%) cases needed observation for $<6 \mathrm{~h}$ in the ER and discharged, 38 (5.6\%) cases admitted for 1 day, 20 (3\%) cases admitted for 2 days, 10 (1.5\%) cases admitted for 3 days, 5 (0.7\%) cases admitted for 1 week and 4 (0.6\%) cases admitted for $>1$ week (Table 10$)$.

As regard management, 12 cases needed endotracheal intubation and mechanical ventilation, 5 cases were shocked and needed dopamine as vasopressor, 31 cases received corticosteroid, 45 cases received bronchodilator by nebulizer and all cases received $\mathrm{O} 2$ therapy and antibiotics (Table 11).

In this study, $66 \%$ of symptomatic survived and $100 \%$ of died cases had hyperthermia, $70 \%$ of symptomatic survived and $100 \%$ of died cases had tachycardia, while $1.5 \%$ of symptomatic survived and $50 \%$ of died cases had hypotension. Respiratory distress was detected in $67 \%$ of symptomatic survived and $100 \%$ of died cases. In addition, CNS abnormalities were detected in $9 \%$ of symptomatic survived and $60 \%$ of died cases. Also vomiting occurred in $43 \%$ of symptomatic survived group and $70 \%$ of the died group and acidosis occurred in $46 \%$ of symptomatic survived group and $100 \%$ of the died group. Moreover mechanical ventilation was used in 3\% of symptomatic survived group and $100 \%$ of the died group. The statistical analysis revealed that the group of deaths showed significant predominance of hyperthermia, tachycardia, hypotension, abnormal respiratory rate, CNS abnormality, acidosis and need of mechanical ventilation when compared with the survivors group. An insignificant difference was detected between both groups as regards vomiting. (Table 12).

The Logistic regression analysis revealed that hypotension, CNS abnormalities, acidosis and need of mechanical ventilation all are predictors of in-hospital mortality (Table13).

Table 1: Distribution of hydrocarbon poisoned cases in the years 2015 and 2016

\begin{tabular}{|c|c|c|c|}
\hline year & No of cases & hydrocarbon cases & \% \\
\hline $\mathbf{2 0 1 5}$ & 21898 & 339 & $1.5 \%$ \\
\hline $\mathbf{2 0 1 6}$ & 23680 & 335 & $1.4 \%$ \\
\hline
\end{tabular}

Table 2: Chi-square statistical analysis of admission and complications among types of hydrocarbons in the years 2015 and 2016

\begin{tabular}{|c|c|c|c|c|}
\hline Type of poison & Benzene 111 & Kerosene 563 & X2 & P \\
\hline Admitted & 22 & 55 & 9.2 & $0.002^{*}$ \\
\hline Died & 2 & 8 & 0.09 & 0.8 \\
\hline Mechanically ventilated & 3 & 9 & 0.6 & 0.4 \\
\hline CNS abnormalities & 4 & 8 & 2.5 & 0.1 \\
\hline
\end{tabular}

$* P \leq 0.05$ is significant. 
Table 3: Distribution of studied cases according to hospital admission place in the years 2015 and 2016

\begin{tabular}{|c|c|c|}
\hline hospital admission place & No of cases & $\mathbf{\%}$ \\
\hline Observation in ER & 597 & $88.6 \%$ \\
\hline In patient word admission & 32 & $4.7 \%$ \\
\hline ICU admission & 45 & $6.7 \%$ \\
\hline Total & 674 & 100 \\
\hline
\end{tabular}

Table 4: Outcome of the hydrocarbon poisoned cases in the years 2015 and 2016

\begin{tabular}{|c|c|c|}
\hline Outcome & No of cases & $\%$ \\
\hline Survived & 664 & $98.5 \%$ \\
\hline Deaths & 10 & $1.5 \%$ \\
\hline Total & 674 & 100 \\
\hline
\end{tabular}

Table 5: Distribution of residence in hydrocarbon poisoned cases in the years 2015 and 2016

\begin{tabular}{|c|c|c|}
\hline Region & No of cases & $\%$ \\
\hline Cairo & 466 & $69 \%$ \\
\hline Kalioubeya & 112 & $17 \%$ \\
\hline Giza & 47 & $6.9 \%$ \\
\hline Upper Egypt Governorates & 27 & $4 \%$ \\
\hline Other Delta Governorates & 18 & $2.6 \%$ \\
\hline Suez Canal Governorates & 4 & $0.5 \%$ \\
\hline Total & 674 & 100 \\
\hline
\end{tabular}

Table 6: Chi-square statistical analysis for age distribution of the hydrocarbon poisoned cases in the 3 studied groups:

\begin{tabular}{|c|c|c|c|c|c|c|}
\hline Age (yrs) & $\begin{array}{l}\text { Asymptomatic } \\
\text { no } 597\end{array}$ & $\begin{array}{c}\text { Symptomatic survived no } 67 \\
\text { no } \quad \%\end{array}$ & $\begin{array}{c}\text { Died } \\
\text { no } 10\end{array}$ & $\begin{array}{c}\text { Total } \\
\text { no } 674\end{array}$ & $\mathrm{X} 2$ & $\mathrm{P}$ \\
\hline & no $\%$ & & no $\%$ & no $\%$ & & \\
\hline$\leq 1$ & $53(9 \%)$ & - & $2(20 \%)$ & $55(8.2 \%)$ & 8.2 & $0.01^{*}$ \\
\hline$>1-\leq 2$ & $218(36.5 \%)$ & $5(7.5 \%)$ & $3(30 \%)$ & $226(33.5 \%)$ & 22.8 & $0.00001^{*}$ \\
\hline$>2-\leq 3$ & $75(12.6 \%)$ & $30(45 \%)$ & $4(40 \%)$ & $109(16.2 \%)$ & 50 & $0.000^{*}$ \\
\hline$>3-\leq 5$ & $42(7 \%)$ & $22(33 \%)$ & $1(10 \%)$ & $65(9.6 \%)$ & 46 & $0.000^{*}$ \\
\hline$>5-\leq 12$ & $29(4.8 \%)$ & $3(4.5 \%)$ & - & $32(4.7 \%)$ & 0.5 & 0.7 \\
\hline$>12-\leq 18$ & $33(5.5 \%)$ & $5(7 \%)$ & - & $38(5.6 \%)$ & 1 & 0.5 \\
\hline$>18-\leq 40$ & $117(19.6 \%)$ & $2(3 \%)$ & - & $119(17.7 \%)$ & 13 & $0.001^{*}$ \\
\hline$>40-\leq 70$ & $30(5 \%)$ & - & - & $30(4.5 \%)$ & 4 & 0.1 \\
\hline
\end{tabular}

$* P \leq 0.05$ is significant.

Table 7: Chi-square statistical analysis for sex distribution of the hydrocarbon poisoned cases in the 3 studied groups

\begin{tabular}{|c|c|c|c|c|}
\hline Sex & $\begin{array}{c}\text { Asymptomatic } \\
\text { no } 597 \\
\text { no } \quad \% \\
\end{array}$ & $\begin{array}{c}\text { Symptomatic survived no } 67 \\
\text { no } \quad \%\end{array}$ & \begin{tabular}{cc}
\multicolumn{2}{c}{ Died } \\
no 10 \\
no $\%$
\end{tabular} & $\begin{array}{l}\text { Total no } \\
\text { no } 674 \\
\text { no } \%\end{array}$ \\
\hline Female & 211 (35\%) & $29 \quad(43.3 \%)$ & $5(50 \%)$ & $245(36.4 \%)$ \\
\hline Male & $386 \quad(65 \%)$ & $38 \quad(56.7 \%)$ & $5(50 \%)$ & $429(63.6 \%)$ \\
\hline Chi-square & \multicolumn{4}{|c|}{2.5} \\
\hline P value & \multicolumn{4}{|c|}{0.3} \\
\hline
\end{tabular}


Table 8: Chi-square statistical analysis for mode of poisoning of the hydrocarbon poisoned cases in the 3 studied groups

\begin{tabular}{|c|c|c|c|c|c|c|}
\hline Mode & $\begin{array}{c}\text { Asymptomatic } \\
\text { no } 597\end{array}$ & $\begin{array}{c}\text { Symptomatic survived no } 67 \\
\text { no } \%\end{array}$ & $\begin{array}{c}\text { Died } \\
\text { no } 10\end{array}$ & $\begin{array}{c}\text { Total no } \\
\text { no } 674\end{array}$ & $\mathrm{X} 2$ & $\mathbf{P}$ \\
\hline & no $\%$ & & no $\%$ & no $\%$ & & \\
\hline Suicidal & $185(31 \%)$ & 7 (10.4\%) & - & $192(28.5 \%)$ & 16 & $0.0002 *$ \\
\hline Accidental & 412 (69\%) & $60(89.6 \%)$ & $8(80 \%)$ & $480(71.2 \%)$ & 12 & $0.001 *$ \\
\hline Criminal & - & - & $2(20 \%)$ & $2(0.3 \%)$ & 133 & $0.000 *$ \\
\hline
\end{tabular}

$* P \leq 0.05$ is significant.

Table 9: Chi-square statistical analysis for routes of poisoning of the hydrocarbon poisoned cases in the 3 studied groups

\begin{tabular}{|c|c|c|c|c|c|c|}
\hline Route & $\begin{array}{cc}\text { Asymptomatic } \\
\text { no } & 597 \\
\text { no } & \% \\
\end{array}$ & $\begin{array}{cc}\text { Symptomatic survived } \\
\text { no } & 67 \\
\text { no } & \% \\
\end{array}$ & \begin{tabular}{cc}
\multicolumn{2}{c}{ Died } \\
no & 10 \\
no & $\%$ \\
\end{tabular} & \begin{tabular}{rr}
\multicolumn{2}{c|}{ Total no } \\
no & 674 \\
no & $\%$ \\
\end{tabular} & $\mathrm{X} 2$ & $\mathbf{P}$ \\
\hline Oral & $592(99.2 \%)$ & $52(77.6 \%)$ & $10(100 \%)$ & $654(97 \%)$ & 0.6 & 0.7 \\
\hline Dermal & $5(0.8 \%)$ & $10(15 \%)$ & - & $15(2.3 \%)$ & 1.7 & 0.4 \\
\hline Injection & - & $5(7.4 \%)$ & - & $5(0.7 \%)$ & 45 & 0 \\
\hline
\end{tabular}

Table 10: The period of hospitalisation of the hydrocarbon poisoned cases

\begin{tabular}{|c|c|c|}
\hline Period of hospitalization & No & $\mathbf{( \% )}$ \\
\hline$<6$ hours & 597 & $88.6 \%$ \\
\hline 6 hours - <1day & 38 & $5.6 \%$ \\
\hline$>$ 1day - 2 days & 20 & $3 \%$ \\
\hline$>$ 2 days -3 days & 10 & $1.5 \%$ \\
\hline 4days- $<$ 1week & 5 & $0.7 \%$ \\
\hline$\geq 1$ week & 4 & $0.6 \%$ \\
\hline Total & 674 & \\
\hline
\end{tabular}

Table 11:The type of emergency treatment offered to all hydrocarbon poisoned cases:

\begin{tabular}{|c|c|}
\hline Type of intervention & No \\
\hline Endotracheal intubation & 12 \\
\hline Mechanical Ventilation & 12 \\
\hline Dopamine & 5 \\
\hline Steroid & 31 \\
\hline Bronchodilator Nebiulization & 45 \\
\hline antibiotics & All cases \\
\hline O2 therapy & All cases \\
\hline
\end{tabular}


Table 12: Chi-square statistical analysis of clinical parameters and mechanical ventilation for survived and died groups.

\begin{tabular}{|c|c|c|c|c|}
\hline Parameters & $\begin{array}{c}\text { Symptomatic survived } \\
\text { No }=67\end{array}$ & $\begin{array}{c}\text { Died } \\
\text { No }=10\end{array}$ & Chi-square test $\left(\chi^{2}\right)$ & $\mathbf{P}$ \\
\hline \multicolumn{5}{|c|}{ Body temperature (BT) } \\
\hline Hyperthermia & 44 (66\%) & $10(100 \%)$ & 4.9 & $0.03 *$ \\
\hline Normal & $23(34 \%)$ & - & & \\
\hline \multicolumn{5}{|c|}{ Heart rate (HR) } \\
\hline Tachycardia & 47 (70\%) & $10(100 \%)$ & 4 & $0.05 *$ \\
\hline Normal & $20(30 \%)$ & - & & \\
\hline \multicolumn{5}{|c|}{ blood pressure (BP) } \\
\hline Hypotension & $1(1.5 \%)$ & $5(50 \%)$ & 28.5 & $9 e-8 *$ \\
\hline Normal & $66(98.5 \%)$ & $5(50 \%)$ & & \\
\hline \multicolumn{5}{|c|}{ Respiratory rate (RR) } \\
\hline Abnormal & 45 (67\%) & $10(100 \%)$ & 4.6 & $0.03 *$ \\
\hline Normal & $22(33 \%)$ & - & & \\
\hline \multicolumn{5}{|c|}{ CNS } \\
\hline Abnormal & $6(9 \%)$ & $6(60 \%)$ & 17.2 & $0.0003^{*}$ \\
\hline Normal & $61(91 \%)$ & $4(40 \%)$ & & \\
\hline \multicolumn{5}{|c|}{ Vomiting } \\
\hline Yes & $29(43 \%)$ & $7(70 \%)$ & & \\
\hline No & $38(47 \%)$ & $3(30 \%)$ & 2.5 & 0.1 \\
\hline \multicolumn{5}{|c|}{ Acidosis } \\
\hline Yes & $31(46 \%)$ & $10(100 \%)$ & 10 & $0001 *$ \\
\hline No & $36(54 \%)$ & - & 10 & $0.001^{\top}$ \\
\hline \multicolumn{5}{|c|}{ Mechanical ventilation } \\
\hline $\begin{array}{l}\text { Yes } \\
\text { No }\end{array}$ & $\begin{array}{c}2(3 \%) \\
65(97 \%)\end{array}$ & $10(100 \%)$ & 62.3 & $0.000 *$ \\
\hline
\end{tabular}

$* P \leq 0.05$ is significant, N.B. hyperthermia $\geq 37.5^{\circ} \mathrm{C}-$ tachycardia $>120$ beats $/ \mathrm{min}$, hypotension SBP $<80$ - respiratory distress $(R R<10$ or $>24$ breaths $/ \mathrm{min}$ ) - acidosis $p H<7.35$ 
Table13: Logistic regression analysis of general characteristics as predictors associated with hydrocarbon poisoning -related mortality

\begin{tabular}{|c|c|c|c|c|}
\hline Parameters & $\begin{array}{c}\text { Symptomatic survived } \\
\text { No }=67\end{array}$ & $\begin{array}{c}\text { Died } \\
\text { No }=10\end{array}$ & OR (95\%CI) & $\mathbf{P}$ \\
\hline \multicolumn{5}{|c|}{ Body temperature (BT) } \\
\hline Hyperthermia & 44 & 10 & 11 & 0.1 \\
\hline Normal & 23 & - & 0.6-197 & \\
\hline \multicolumn{5}{|c|}{ Heart rate (HR) } \\
\hline Tachycardia & 47 & 10 & 9 & 0.1 \\
\hline Normal & 20 & - & $0.5-162$ & \\
\hline \multicolumn{5}{|c|}{ blood pressure (BP) } \\
\hline Hypotension & 1 & 5 & 66 & $0.0004 *$ \\
\hline Normal & 66 & 5 & 6.4- 679 & \\
\hline \multicolumn{5}{|c|}{ Respiratory rate (RR) } \\
\hline Abnormal & 45 & 10 & 10.4 & 0.1 \\
\hline Normal & 22 & - & 0.6-185 & \\
\hline \multicolumn{5}{|c|}{ CNS } \\
\hline Abnormal & 6 & 6 & 15 & $0.0004^{*}$ \\
\hline Normal & 61 & 4 & 3.3-69 & \\
\hline \multicolumn{5}{|c|}{ Vomiting } \\
\hline yes & 29 & 7 & 3 & \\
\hline no & 38 & 3 & $0.7-13$ & 0.1 \\
\hline \multicolumn{5}{|c|}{ Acidosis } \\
\hline Yes & 31 & 10 & 24 & \\
\hline No & 36 & - & $1.3-432$ & $0.02^{*}$ \\
\hline \multicolumn{5}{|c|}{ Mechanical ventilation } \\
\hline Yes & 2 & 10 & 550 & \\
\hline No & 65 & - & 24-12281 & $0.0001^{*}$ \\
\hline
\end{tabular}

$* P \leq 0.05$ is significant.

\section{Discussion}

Hydrocarbon exposures are frequent and account for a large number of health care visits and hospital admissions. (Mowry et al., 2014). Therefore in the present study, during the year 2015 and 2016, 339 cases $(1.5 \%)$ and 335 cases (1.4\%) were diagnosed as hydrocarbon poisoning respectively in PCC-AUH. Kar et al.( 2014), found that during the year 2013, 31.031 cases of hydrocarbon poisoning were reported to United States(US) poison control centers. Hydrocarbons were implicated in almost $10 \%$ of all single substance fatalities. Gasoline,kerosene chlorofluorocarbon propellants, motor oils, lighter fluid/naphtha, lamp oil, and mineral spirits, are the most commonly ingested substances (Makrygianni et al., 2016).

Tormoehlen et al. (2014), reported that hydrocarbon toxicity is common as they are usually unsecured or improperly stored in a drinking containers.

In the present study, most of cases of hydrocarbon toxicity were due to kerosene ingestion(563).This was also reported by Sen et al.(2013) in United States (US), who found that kerosene accounted in $90.7 \%$ of hydrocarbon ingestions. Kerosene ingestion is the commonest form of acute childhood poisoning in most developing countries. Nearly 40\% occur in children younger than 6 years (Kar et al., 2014). Kerosene, also known as paraffin, is refined oil obtained by distillation and purification of crude petroleum or rock oil. It is a hydrocarbon, used for cooking, heating and lighting- a cheap fuel which, due to cultural practices, unfortunately is stored in containers and places, which are accessible to children(Bader et al., 2010). The most frequently aspirated hydrocarbon is kerosene in Middle Eastern countries and cleaning products including white spirit in occidental countries (Sankar, 2010).

In this study, there was no significant difference between benzene and kerosene poisoned cases regarding complicattions. Although, there was significant difference regarding admission. This was to prevent systemic complications which occur more rapidly with aromatic than aliphaic hydrocarbons due to their faster absorbtion from gastrointestinal and respiratory systems ( Lewander and Aleguas 2007).

In this study, most of cases were from Cairo $69 \%$ and $17 \%$ were from Kalioubeya. Acute poisoning with hydrocarbones is a common and stable occurrence in crowded low socioeconomic groups in Africa, where negligence is the main cause of poisoning (Benois et al., 2009).

Most of the cases in the present study were males (63.6\%) and there was no significant difference between all groups as regard sex.

Sen et al.(2013), foumd that $64.8 \%$ of the patients were male, $35.2 \%$ were female in Turkey.

In the current study, most of cases were in the age group $>1-\leq 2$ years $(33.5 \%)$ followed by age $>18-$ 
$\leq 40$ years $(17.7 \%)$, all died cases were children and $40 \%$ of these deaths were in the age group ( $>2$ $\leq 3$ years). Bronstein et al. (2010), foumd that hydrocarbon ingestion accounts for one to two percent of non-pharmaceutical exposures in children younger than six years of age reported to US poison control centers in 2009 .Also Kar et al.( 2014), reported that $31 \%$ of hydrocarbon poisoned cases were in children younger than 6 years of age, and another $12 \%$ were in older children and teenagers in US poison control centers during 2013.

In addition, most of symptomatic cases (89.6\%) and died patients(80\%) used accidental mode of toxicity and oral route was present in $97 \%$ of cases (;77.6\% of symptomatic and all dead patients) ,while $2.3 \%$ were due to dermal route of poisoning and the injection route was $0.7 \%$. One should also keep in mind that in $>90 \%$ of cases, poisoning in young children is accidental. It results from unique tendency of younger children to put everything in their mouth (Bader et al., 2010).

About $75.9 \%$ of over 40,000 visits to emergency departments in US for hydrocarbon-related exposures in children 5 years of age or younger were accidental ingestions (Makrygianni et al.,2016) About one-third of hydrocarbon ingestions reported in the U S involve children 5 years of age or younger and they are mainly due to accidental ingestion (Mowry et al., 2013) Only $8.2 \%$ of visits to emergency departments in US for potential hydrocarbon poisoning were due to inhalation (Tormoehlen et al., 2014).

Bader et al., (2010) reported that oral intake is a common route of poisoning but topical, dermal, ophthalmic and inhalational may also be seen quite often. Infants and children younger than 5 years of age are the common victims of poisoning in Pakistan.

In contrast, Ramnarine and Facep( 2015) , found that exposure of adolescents to hydrocarbons in US is mostly the result of abuse by inhalation.

The highest rates of morbidity and mortality result from accidental ingestion by children younger than 5 years in US (Makrygianni et al., 2016). Sheikh et al. (2013), found that upon ingestion in US, 35-54\% of children are symptomatic. This is because hydrocarbon aspiration may cause death secondary to respiratory failure in this pediatric population.

In this study,all died cases complained of hyperthermia due to pnumonitis. Lewander and Aleguas( 2011), found that between 30 and $60 \%$ of cases with hydrocarbon aspiration have fever at the time of presentation ( 38 to $40^{\circ} \mathrm{C}$ ). Persistence beyond 48 hours suggests bacterial superinfection.

The present study showed that respiratory distress was detected in $67 \%$ of symptomatic survived and all died cases. This respiratory distress was tachypnea due to pnemonitis or bradypnea with or without irregular breathing due to CNS depression .This study also revealed that hypoxia required mechanical ventilation was observed in all dead cases. Lewander and Aleguas(2011), reported that pulse oximetry may show decreased oxygen saturation which was noticed as a bad prognostic sign.
Aspiration pneumonitis is the most common complication of hydrocarbon ingestion, followed by CNS and cardiovascular complications. (Tormoehlen et al., 2014).

Pulmonary injury results from aspiration during or after the hydrocarbon ingestion (Jolliff et al., 2013). Among hydrocarbons those with low viscosity and surface tension, such as kerosene, lighter fluid, lamp oil, and naphtha, are frequently associated with clinically significant effects on the respiratory system. Chemical pneumonitis, respiratory distress, and a variety of air-leak syndromes may occur (Sheikh et al., 2013). In a study made by Makrygianni et al. (2016) in US, aspiration pneumonitis occurred in approximately $15 \%$ of ingestions, and evolves over the first $6-8$ hours

Chest radiographic abnormalities develop by 4-8 hours after ingestion, but they are not always predictive of clinical pneumonitis. cases with history of hydrocarbon ingestion should be monitored for 68 hours in the emergency department and a chest radiogram should be obtained at the end of the observation period. As none of the individuals who were asymptomatic initially became symptomatic or developed complications later on although early gasping, choking, coughing, and vomiting are signs of hydrocarbon aspiration, they may or may not progress to chemical pneumonitis (Makrygianni et al., 2016).

While most aliphatic hydrocarbons have little gastri intestinal absorption, aspiration frequently occurs, either initially or in a semidelayed fashion as the patient coughs or vomits, thereby resulting in pulmonary effects. Once aspirated, the hydrocarbons can create a severe pneumonitis (kar et al., 2014).

Hydrocarbon pneumonitis results from a direct toxic effect by the hydrocarbon on the lung parenchyma. The type II pneumocytes are most affected, resulting in decreased surfactant production. This decrease in surfactant, results in alveolar collapse, ventilation-perfusion mismatch, and hypoxemia requiring mechanical ventilation (Balme et al., 2015).

CNS abnormalities were detected in $9 \%$ of symptomatic survived and $60 \%$ of died cases . Central acute effects included CNS depression (eg, lethargy, coma) or seizuresfound that acute systemic toxicity following .

CNS toxicity can result from several mechanisms, including direct injury to the brain or indirectly as a result of severe hypoxia or simple asphyxiation (Jolliff et al., 2013).

Compounds that are lipophilic are able to cross the blood-brain barrier, leading to CNS effects (Levin, 2015). Halogenated and aromatic hydrocarbons are easily absorbed through respiratory and gastrointestinal mucosa, often leading to CNS toxicity (Ramnarine and Facep, 2015).

In the present study, all died cases complained of tachycardia and $50 \%$ of them complained of hypotension. Tachycardia was secondary to respiratory distress and acidosis because the myocardium becomes sensitized to the effects of catecholamines, which can predispose the patient to any type of 
tachydysrhythmias, which can result in syncope or sudden death (Levine, 2017).

In the present study, vomiting occurred in $43 \%$ of symptomatic survived group and $70 \%$ of the died group .Many of the hydrocarbons create a burning sensation because they are irritating to the GI mucosa. Vomiting has been reported in up to one third of all hydrocarbon exposures (Levine, 2017).

In the current study, most of cases (88.6\%)needed observation for $<6$ hours in the ER ,while $4.7 \%$ needed admission in the inpatient word,6.7\% admitted to ICU and 1.5\% died . Kar et al. (2014), found that moderate outcomes were reported in about $54.7 \%$ of cases, major outcomes in $3.9 \%$, and death in $0.6 \%$ of cases in US poison control centers in the year 2013.

Tormoehlen et al. (2014), found that approximately $90 \%$ of hospitalized hydrocarbon poisoned cases have a benign clinical course. Children who are symptomatic are admitted to the hospital for cardiorespiratory status monitoring and supportive care Increased work of breathing with or without altered sensorium and seizures are indications for admission to the intensive care unit (Jolliff et al., 2013).

In the current study, all cases presented with acidosis died, it was mostly respiratory acidosis and to less extent metabolic acidosis.Acidosis is either respiratory due to central or peripheral respiratory failure and/or metabolic due to multisystem organ failure or renal failure complicating hydrocarbon toxicity (Tormoehlen et al., 2014).

The present study revealed that 2 cases needed endotracheal intubation and mechanical ventilation, 5 cases were shocked and needed dopamine as vasopressor, 31 cases received corticosteroid, 45 cases received bronchodilator by nebulizer and all cases received $\mathrm{O} 2$ therapy and antibiotics. Makrygianni et al.

\section{Conclusion}

It was concluded that hydrocarbon poisoning is common oral accidental toxicity among children in the age group $>1-\leq 2$ years.

In hydrocarbon poisoning, any of the following presentation is considered as a predictor of fatal outcome: children especially the age group $>2-\leq 3$ years, hyperthermia, tachycardia, hypotension, respiratory distress, CNS abnormalities and acidosis.

\section{Recommendations}

Any case presented with the previously mentioned predictors should be considered as a high risk group for proper management and in order to decrease risk of fatalities.

Preventive measures should be done as awareness of parents about hydrocarbon toxicity, proper packing and storage of such dangerous materials.

\section{References}

Abd El Salam H, Fayed A, Abdel Muneum M (2011): Prediction of the Outcome of Patients with Acute Hydrocarbons Poisoning using Poison Severity Scoring System; A Prospective Study :Journal of American Science,;7(4)
(2016) observed that hypoxemia unresponsive to supplemental oxygen and/or severe central nervous system involvement require mechanical ventilation. Corticosteroids do not seem to offer any benefit and antibiotics are administered in cases of bacterial superinfection.Also, Madboly and Elgendy( 2014), found that no specific treatment was needed for cases of hydrocarbone toxicity in Benha Poisoning Control Unit ;only supplemental oxygen in $86.1 \%$ of cases,only $5.6 \%$ were mechanically ventilated.

The current study's Logistic regression analysis revealed that hypotension, CNS abnormalities, acidosis and need of mechanical ventilation all are predictors of in-hospital mortality. In addition, all the group of deaths showed significant predominance of hyperthermia, tachycardia, hypotension, abnormal respiratory rate, CNS abnormalities, acidosis and need of mechanical ventilation when compared with the survivors group. An insignificant difference was detected between both groups as regards vomiting. All died cases were children, $40 \%$ of them were $>2$ $\leq 3$ years and all died cases used oral route.

In contrast, previous researches related death to abnormalities in respiration and CNS only; Gamaludin et al.(2009), suggested a triage decision rule based on the presence of wheezing,altered consciosness and a rapid respiratory rate whithin 2 hours of exposure.Also Jayashree et al.(2006), found that signs of severe respiratory distress ,history of lavage, and leucocytosis at admission are associated with poor outcome. The main causes of mortality group in a study by Abd El Salam et al.(2011), were multiple organ failure (acute respiratory distress syndrome, arrhythmias, renal failure, consumptive coagulopathy and coma) secondary to respiratory failure and not to direct toxic insult.

Bader R, Ashfaq M, Cha Y, (2010): Kerosene oil ingestion among children presenting to the emergency department of a Tertiary Care Pediatric Hospital Vol. 34(2) June

Balme K, Zar H, Swift D, et al., (2015) The efficacy of prophylactic antibiotics in the management of children with kerosene-associated pneumonitis: a double-blind randomised controlled trial. Clin Toxicol (Phila). Jun 26. 1-8.

Benois A, Petitjeans F, Raynaud L et al., (2009) Clinical and therapeutic aspects of childhood kerosene poisoning in Djibouti .Tropical Doctor J October, 39;266-238

Borne J, Riascos R, Cuellar H, (2005) Neuroimaging in drug and substance abuse part II: opioids and solvents. Top Magn Reson ImagingJun. 16(3):239-45.

Bronstein A, Spyker D, Cantilena L , et al. (2010): Annual Report of the American Association of Poison Control Centers' National Poison Data System (NPDS): 27th Annual Report. Clin Toxicol (Phila); 48:979.

Dahiru T. (2008): P-value, a true test of statistical significance? A cautionary note. Annals of Ibadan postgraduate medicine 6: 21-26. 
Food and Drug Administration. FDASIA Health IT Report, Proposed Strategy and Recommendations for a Risk-Based Framework.

http://www.fda.gov/downloads/AboutFDA/CentersOffi ces/OfficeofMedicalProductsandTobacco/CDRH /CDRHReports/UCM391521.pdf (accessed 5/13/2014).

Gamaludin M,Elgundi M, Sakr M, (2009): A clinical decision rule for triage of children under 5 years of age with hydrocarbon(kerosene) aspiration in developing counteries.j toxicol.vol 46;222-229

Jayashree M,Singh S ,Gupta (2006): A predictors of outcome in children with hydrocarbon piosoning receicing intensive care. Indian Pediatrics ;43:715-710

Jolliff H, Fletcher E, Roberts K, et al. (2013): Pediatric hydrocarbon-related injuries in the United States: 2000-2009. Pediatrics;131:1139-1147.

Kar S, Choudhuri R, Adhikari D, et al. (2014): Acute Necrotising Pneumonia with Bronchiectatic Changes and Transaminitis following Kerosene Ingestion: An Unusual Acute Presentation.Clin Toxicol (Phila);51:871-878. 100:4

Levine D, (2015): Hydrocarbon Toxicity .http//misc medscape. com. Article 821143.

Levine D, (2017): Hydrocarbon Toxicity http://emedicine. medscape. com/ article/ 821143- overview\#a1

Lewander W and Aleguas A, (2011): Hydrocarbon poisoning. Tropical Doctor J; 39: 236-238

Lewander W, Aleguas A. (2007): Petroleum distillates and plant hydrocarbons. In: Haddad and Winchester's Clinical Management of Poisoning and Drug Overdose, 4th, Shannon MW, Borron SW, Burns MJ. (Eds), Saunders Elsevier, Philadelphia. p.1343.

Madboly A and Elgendy F, (2014): Epidemiology, Clinical Characteristics and Management of Acute Hydrocarbons Poisoning at Benha Poisoning Control Unit: A One Year Prospective Clinical Study.Ain Shams J. Forensic. Med. Clin. Toxicol.23, 30-42.

Makrygianni A, Palamidou F, Athanasios G. (2016): Respiratory complications following hydrocarbon aspiration in children. Pediatric Pulmonary J Volume 51, Issue 6 June Pages 560-569
McGinn T, Guyatt G, Wyer P, et al. (2000). Users' guides to the medical literature: XXII: how to use articles about clinical decision rules.

Evidence-Based Medicine

WorkingGroup. JAMA. 284 (1): 79-

84.doi:10.1001/jama.284.1.79. PMID 10872017

Mowry J, Spyker D, Cantilena L, et al. (2013): Annual Report of the American Association of Poison Control Centers' National Poison Data System (NPDS): 30th Annual Report. Clin Toxicol (Phila);51:949-1229.

Mowry J, Spyker D, Cantilena L, et al. (2014): Annual Report of the American Association of Poison Control Centers' National Poison Data System (NPDS): 31st Annual Report. Clin Toxicol (Phila). Dec. 52 (10):1032-283.

Osheroff, Teich, Levick et al., 2012. Improving outcomes with CDS: an implementer's guide, Second Edition

Primm, A. (2008): Hydrocarbon aspiration in children and adolescents. Last literature review version 16.1: Janeiro;1-5 updated: Setembro 13

Ramnarine $M$ and Facep (2015): Hydrocarbons Toxicity.J of Pediatrics: Cardiac Disease and Critical Care Medicine.

Sankar J (2010): Hyroarbon toxiity.The Indian Journal of Emergency Pediatrics ;Volume 2 Number 2, April - June

Schneider S, Schurch D, Geiser M. (2013): Aspiration toxicology of hydrocarbons and lamp oils studied by in vitro technology. Toxicol In Vitro; 27: 1089-1101

Sen V, Kelekci S, Selimoglu H et al. (2013): An evaluation of cases of pneumonia that occurred secondary to hydrocarbon exposure in children; Suppl 1 17: 9-12

Seymour F (2001): Assessment and management of acute poisoning by petroleum products .Human \& Experimental Toxicology (2001) 20, 551 -562

Sheikh S, Chang A, Kieszak S et al. (2013): Characterizing risk factors for pediatric lamp oil product exposures. Clin Toxicol (Phila);51:871878.

Tormoehlen L, Tekulve K, Nanagas K. (2014): Hydrocarbon toxicity: a review. Clin Toxicol (Phila) ;52:479-489. 
الملخص العربي

تكهنات قاعده القرار السريريه لحالات التسمم بالهايدروكاربون التي ادخلت لمركز علاج التسمم مستشفيات

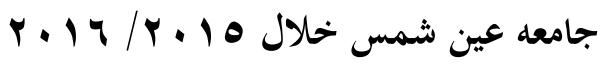

\section{هاني محمد توفيق' ورباب نبيل حافظ}

التسمم بالهايدروكاربون هو سبب شائع للوفيات بين مرضى مراكز علاج التسمم وذلك بسبب مضاعفاته الخطيره ـ الغرض من هذا البحث

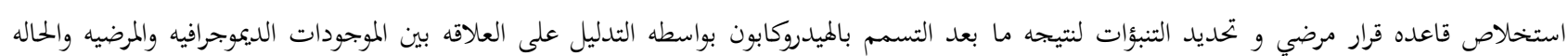

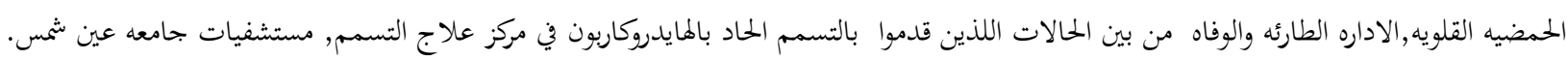

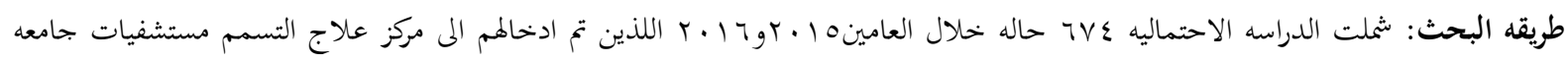

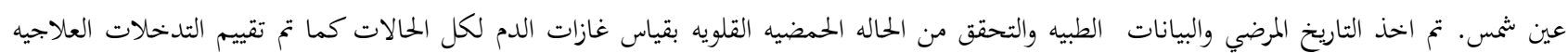

النتائج: كآه حالات حضروا بالتسمم من الكيروسين, 111 الحاله بالتسمم من البنزين, يوجد تغير ذو دلاله احصائيه بين نوعي التسمم

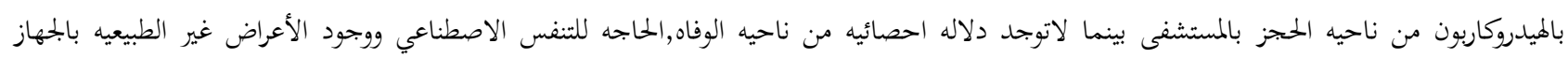

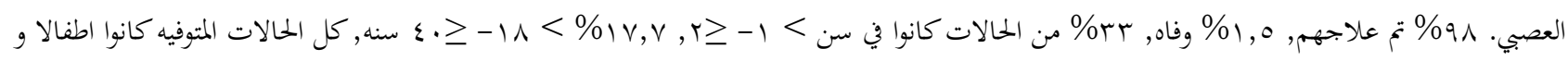

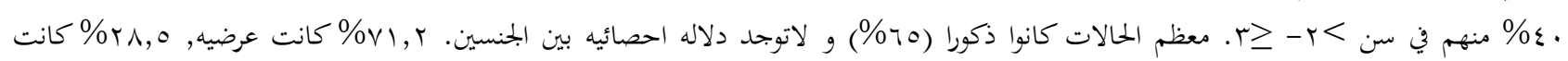

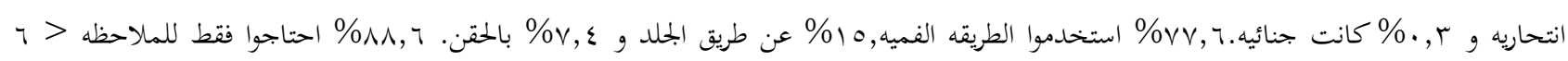

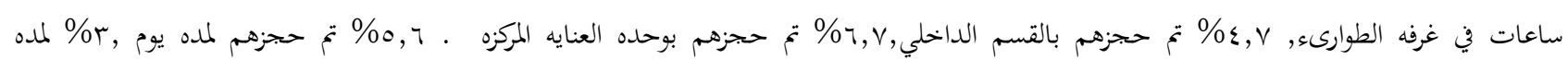

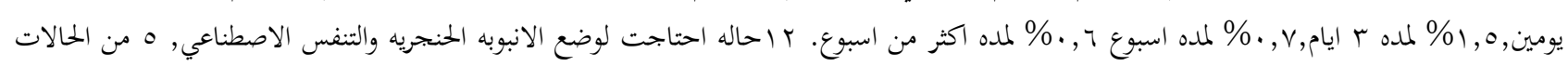

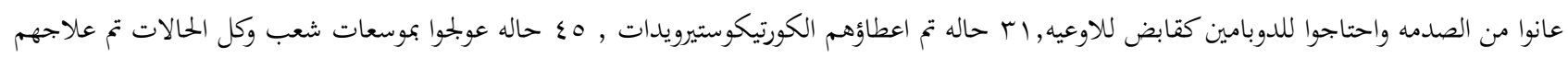

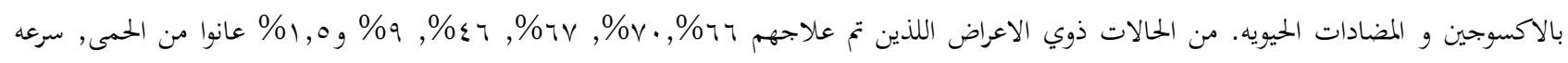

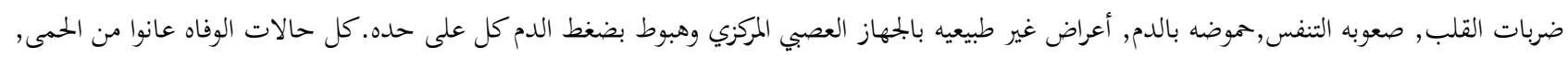

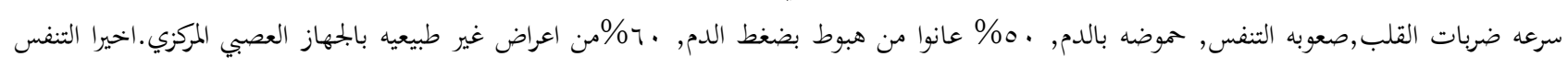

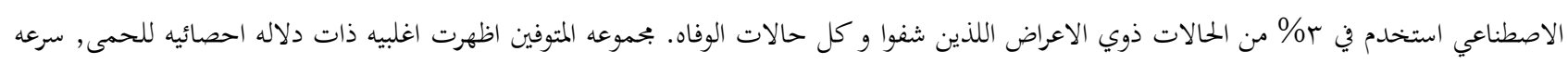

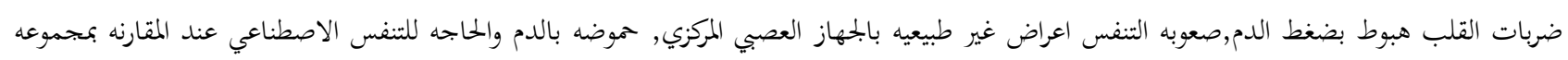

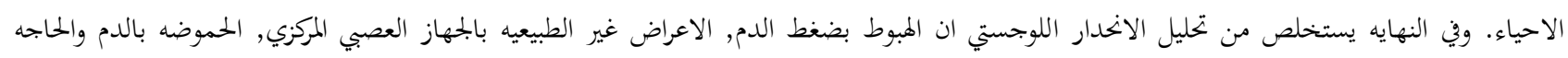

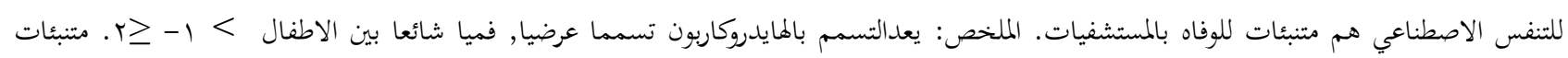

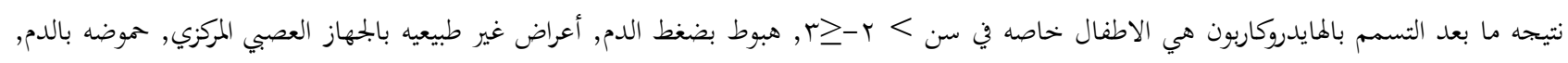

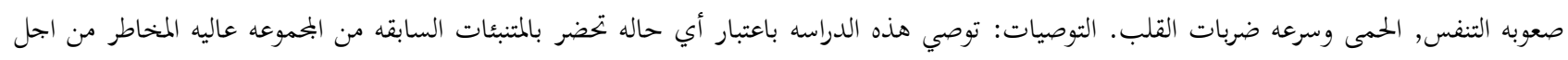

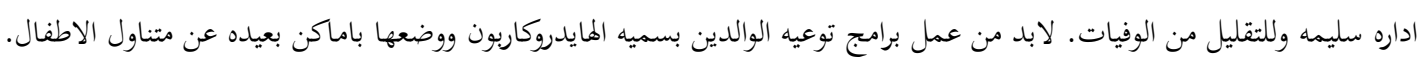

' مركز علاج التسمم مستشفيات جامعه عين شمس - القاهرة - مصر ب قسم الطب الثرعى والسموم الاكلينيكيه كليه الطب, جامعه عين شمس - القاهرة - مصر 